\title{
Controlled Freedom - the Formation of the Control Society
}

\author{
Ludwig A. Pongratz
}

Abstract: My analysis develops via the following five conceptual steps. The first step links up with Foucault's analysis of techniques of ,soft' discipline, which relates to ,classical' reform pedagogy, in the transition period from the 19th to the 20th century. The second step thematises the shifts in these disciplinary techniques in the context of the crisis of the so-called,environments of enclosure'. Here there is a particular focus on Deleuze's arguments concerning the emergence of a modern ,society of control'. The third step considers the specific form of the government of the social', which Foucault approaches with the concept of governmentality'. The fourth step aims to show that the current educational reforms can be understood as a governmental strategy'. The fifth step, finally, thematises the inconsistency of governmental practices. It pursues the possibility that such practices advance, en passant or contrary to their aims, their own contradiction: the preparedness and capacity for critical opposition.

Keywords : environments of enclosure, control society, critique, disciplinary society, educational reform, governmentality, panopticism, quality management, reform pedagogy

\section{'Environments of enclosure': reform pedagogy as 'soft' discipline}

I will begin with a short look back at the old days of reform pedagogy, the period in which educationalists turned towards the introduction of new strategies of control to replace the rigid disciplinary forms of the 19th century. Much like the current context, these reforms were put forward under the banner of freedom and progress, renewal and realism. Reform Pedagogy's shift from the old forms of drill and rote-learning to dynamic, inner-directed learning forms aimed to move, as quickly as possible, from external to internal regulation: teaching becomes 'community teaching', the school class turns into a 'living and working community'. Certainly school pupils 
are taken more seriously as autonomous subjects than they had been previously, but not least in order to integrate them more smoothly into the institutionally established framework of the school.

One can illustrate this shift from 'drill pedagogy' to 'reform pedagogy' with the example of the teacher's relationship to the school pupil's trouser pockets: the 'old' pedagogy examined trouser pockets only to ensure they contained clean handkerchiefs, the 'new pedagogy' did precisely the reverse, emptying all the contents onto the table in order to gain an insight into school life and to make the youthful collector's passions pedagogically useful [Kost 1985: 109f]. Foucault helps us to summarise the essence of the new, soft forms of discipline: the constant concern is to render things visible and capable of being articulated. The subjective interest in the school pupil is thus imperceptibly coupled with the objective interest of the school system in the development of individual capacities and the reintegration of these capacities into a unified whole, the functional principles of which remain concealed from the individual - precisely because everything appears to be out in the open. In this way the learning situation is reorganized according to the principle of 'panopticism', so that the disciplinary network is no longer organised in terms of administrative decrees, but more in terms of the ultra-flexible steering mechanisms of 'school life'. This is how soft control takes the form of - as Foucault puts it - a generalised "political technology" [Foucault 1977: 205].

A precondition for this political technology, however, is the establishment of enclosed environments, as they arose in the course of the $19^{\text {th }}$ and $20^{\text {th }}$ centuries. The city wall or the tower in Bentham's Panopticon symbolises clearly the institutional presuppositions under which the new disciplinary techniques could express their effects: the disciplinary effects of 'school life' are tied to observable 'communities', in which everyone can see everyone else, that is, everyone is expected to display and substantiate themselves. Panopticism requires a 'framework', a 'life circle" (as the Reform Pedagogue Gaudig referred to it), a specific environment (whether the micro-environment of a group-dynamic setting or the macro-environment of a residential area). In a certain sense one could say: in a circle, the technique of soft discipline concentrates itself both symbolically and in reality: from the 'circle of chairs' to 360 degree feedback, from the 'morning round' to the quality circle, from team conversation to the roundtable.

\section{Control society: the crisis of confinement milieus}

What happens, though, when social environments fall into crisis, when they begin to dissolve? It is now no longer a secret that they are in crisis, 
since the last third of the 20th century. ,We are,' wrote Deleuze, in a generalized crisis in relation to all the environments of enclosure - prison, hospital, factory, school, family [...] The administrations in charge never cease announcing supposedly necessary reforms: to reform schools, to reform indsutries, hospitals, the armed forces, prisons. But everyone knows that these institutions are finished, whatever the length of their expiration periods. It's only a matter of administering their last rites and of keeping people employed until the last installation of the new forces knocking on the door. These are the societies of control, which are in the process of replacing the disciplinary societies [Deleuze 1992: 3-4].

This sentence was written in 1990. It appears in a short, comprehensive piece, only a few pages long, by Gilles Deleuze with the concise title ,Postscript on the Societies of Control', published two years later in October [Deleuze 1992], and then as a book chapter in 1995 [Deleuze 1995]. I first took the text into serious consideration around 10 years later, when everything that Deleuze had seen coming much earlier than I was already well underway. Here I will draw only on those of his ideas immediately relevant to the concerns of this discussion. First: if the disciplinary society (the 19th and most of the 20th centuries) found its genuine expression in acts of disciplining and normalisation, the subsequent control societies, in contrast, develop a new repertoire of management techniques. Today ,discipline' and ,norm' are long past guaranteeing productivity; in their place one finds ,flexibility', ,motivation', goal coordination', or ,self-management'. Deleuze thematises this transformation in terms of the shift from the factory' to the ,corporation'. „The factory, " he wrote, "constituted individuals as a single body [...] but the corporation constantly presents the brashest rivalry as a healthy form of emulation, an excellent motivational force that opposes individuals against one another and runs through each, dividing each within [1992: 4-5]. In his own concise, illustrative language, Deleuze draws out the crucial distinction: „Enclosures are molds, distinct castings,“ he wrote, „but controls are a modulation, like a self-deforming cast that will continously change from one moment to another [...] [p. 4].

The ,corporation' does not, however, simply replace the factory', it becomes the generalized model for all of the new forms of control. It links freedom and domination in the paradoxical figure of ,voluntary self-control' [Pongratz 2004]. ,The family, the school, the army, the factory,' wrote Deleuze, ,are no longer the distinct analogical spaces that converge towards an owner - state or private power - but coded figures - deformable and transformable - of a single corporation that now has only stockholders' [Deleuze 1992: 6].

If Deleuze already knew the direction to be taken by ,I-Corp', it would have been spelled out at this point. The basic elements of this transformatory 
process have in the meantime moved far ahead: Deleuze's formulation anticipates the commentary on current educational reform: ,Just as the corporation replaces the factory, perpetual training tends to replace the school, and continuous control to replace the examination. Which is the surest way of delivering the school over to the corporation. In the disciplinary societies one was always starting again (from school to the barracks, from the barracks to the factory), while in the societies of control one is never finished with anything [...]' [1992: 5]. All of life becomes a preparation for life. Or, in other words: one's whole life appears as a single, volatile modulation.

\section{Governmentality: the conduct of conduct}

From this perspective it becomes possible to comprehend why the current pedagogic mainstream propagates a new regime: the regime of lifelong learning. It also becomes possible to understand why pedagogy is to be transformed into a science of the lifecycle. Pedagogy's program of transformation responds in a certain sense to what Deleuze and Foucault diagnosed as the ,crisis of the environments of enclosure', or what was also thematised at the time in social policy terms as the ,crisis of the welfare state'. We have more or less become used to the problematisation of welfare state guarantees and social security systems: their deprecation has in the meantime become part of political everyday life. It makes it possible for the new forms of the governing the social' - which attempt to respond to the ,crisis of the environments of enclosure' - to appear plausible.How are these new forms of government constituted? At the heart of the new mode of governance stands the tendential transition from public to private security, from societal to individual risk management, from social insurance to self-responsibility, from state welfare to self-care. The aim of this change programme is the socio-political construction of subjects who are more conscious of responsibility, and that means being more responsble both towards themselves and soceity, and at the same time more ,economic' and ,moral'[Lessenich 2003: 86].

The current transformation is thus characterized not just by economic or social processes of deregulation, but also, running parallel, a ,moral rearmament'. What is demanded is not just an economically calculative selfrelationship, but the constant demonstration of self-responsibility, private care and self-managed prevention. ,In this context, under-socialised - that is, work-shy, prevention-refusing, activation-resistant - subjects constitute threats to the social - economically, as investement failures, and morally, as beneficiaries of solidarity"[Lessenich 2003: 89]. It then becomes a corresponding requirement of people that they constantly observe themselves, becoming their own mirror (or ,confessional mirror'). The many-sided, per- 
manent, panoptic external gaze turns in a certain sense inwards: the new moral subjects become their own observers, controllers, investors, in short, their own entrepreneurship.

This displacement of steering capacities from centralising instances to ,self-responsible' and ,self-organised' units marks a fundamental upheaval in forms of governance: from (hard or soft) forms of discipline to new forms of governmentality'. The concept of governmentality has these days become discussed quite widely, so I will here refer briefly only to Foucault's later work. His arguments concern the ,practices of subjectification' in contemporary societies, that is, the practices that take control of individuals, in the sense of urging them towards permanent self-examination, self-articulation, self-interpretation and self-optimisation [Pongratz 2005: 28 ff.]. They address the question of how of how forms of political governance are associated with specific techniques of (self) management; or in other words, how ,logics of governance' and ,practices of subjectification' are linked together. Foucault then shows how the restructuring of state and society is oriented more towards identifying and developing technologies of the self which can be coupled with governmental aims. In the context of neoliberal governmentality, self-determination, responsibility and freedom of choice signal „not the limits of government action, but are themselves an instrument and vehicle for the transformation of the relation of the subject to themselves and to others"[Lemke, Krasman, Bröckling 2000: 30].

In the wake of this shift, pedagogy acquires great significance: schooling and further education, educational institutions and social work are bound up in a strategic complex oriented towards recoding social relations on the basis of a new topography of the social. Educational reform appears from this perspective as a governmental strategy par excellence.

\section{Voluntary self-control: educational reform as 'governmental strategy'}

How this strategy achieves its effects becomes apparent at various levels of the education system [Pongratz 2004: $253 \mathrm{ff}$.$] .$

- Just as wage labourers are to become ,labour entrepreneurs' [Voß Pongratzt 1998], I Ltds' or ,intrapeneurs', students are redefined as knowledge self-managers, autopoietic ,learning systems', for whom sucess is held out particularly when they acquire the qualities of modern management: acquiring the means of production for the creation of knowledge (learning to learn), subjecting themselves to the self-constraint of permanent quality contol and optimisation (motivation management), learning to see themselves as both clients and private suppliers on the education 
market (self-management), exposig themselves to permanent control, examination and certification (self-optimisation), and so on. Every student and every teacher becomes their own ,competence centre'; accordingly, the concept of competence moves to the centre of pedagogic reflection. Competence is here understood as the individual disposition towards self-organisation, as the totality of the „requirements of a person, a team, an organisation or an enterprise to act with some level of certainty in situations with guaranteed uncertain outcomes"[Erpenbeck 2001: 206]. Competencies are meant to secure the possibility of self-managed learning in the "jungle of the globalised market" [206]. Learning becomes self-managed when "the learning goals and the operations and strategies which lead to those goals are determined by the learning system itself" [204]. The subtle transformation of self-management into self-determination, however, ultimately disguises the socio-technical instrumentalisation of learning processes which accompany the discourse of competency. Self-management aims at only a segment of what used to be understood as self-determination, at functional behaviour.

- Implicitly the concept of self-management makes it clear that there is no longer anything the self can hold on to, other than itself. Given the uncontrollable relationships which gather around it, that is precious little. The fact that in the jungle of market relationships there are no more securities which can guarantee success with one's chosen strategies, is echoed in the constructivist thesis of the ,unintendedness' and contingency of learning. The fact that everyone has to give their all, so as not to loose their place, is expressed in the maxims of ,viability' and ,receptiveness', against which the outcomes of learning processes are measured. At the level of the teaching process, a new vocabulary is thus set in motion, which constructs teaching as a sort of learning management, as the arrangement and steering of learning situations, in which it is ultimately up to the individual to make the best of it (or to fail to do so). In a direct translation of the enabling strategies of private enterprise management, pedagogic approaches informed by systems theory and constructivism propagate a new sort of ,enabling didactics' [Arnold, Siebert 1995]. They sanction at the didactic-methodological level the transition from Fordist forms of educational production (with operationalised guidelines, defined elements of the curriculum and a corresponding set of methods) to post-Fordist steering models. The mode of social steering is shifted from an expert-oriented regimentation to a mobile adaption strategy oriented to subjects as clients. Uncertainty and contingency are thus subjectively redefined. They are perceived „no longer simply as threat [...] but as a field of freedom and thus as a resource to be exploited" [Bröckling cited in Bröckling, Kras- 
mann, Lemke (Hrsg.) 2000: 133]. Corresponding learning arrangements have the task of both enabling the desired practices of subjectification and placing functional limits around them. Use is then made of the older reform pedagogic models, the subterranean-irrational patterning of which is still effective: „All the pedagogic elements which were once considered in terms of the formation of autonomous subjects, project learning, situation learning, complex learning and much more, resurface as a new means by which ultimately the entrepeneurial construction of a more comprehensively needed subject can be realised“ [Röder 1989: 186]. This makes possible a general form of management with premises that are irrational, an execution which is rational, and a tendency which is comprehensive.

- This is realised at an insitutional level with the reorganisation of educational institutions as market-oriented service centers. Their goal is no longer ,education' (Bildung), but the privatisation and commercialisation of knowledge; educational processes are transformed into private property transactions with knowledge as a commodity. What used to be understood as the genuine pedagogic task of the institution is now dealt with formally according to the framework of enterprise project development. Running a school or an istitution of further education becomes a project management task, with the aim of introducing new products and guiding internal restructuring. „The school leaver as branded product - this is how one could capture the secret program of current concerns with education reform in a concise formula"[Fischbach 2002: 11]. The teacher disappears in a corresponding way, to reappear as project leader or evaluation manager [Schirlbauer 1998: 56]. The effectiveness and efficiency of the enterprise as a whole is no longer to be ensured through partial measures, but produces a manifest demand for organisational and personal development. It establishes a „permanent quality tribunal” [Simons 2002: 617 ff.], which hides socially produced economic laws behind the veil of inevitability and naturalness. The naturalisation of governmental strategies includes smooth-talking the mechanisms of disciplining. "There is a whole game with the connotations and associations of words like flexibility, capacity for adaption, deregulation, promoting the belief that the neo-liberal message is one of general liberation"[Bourdieu 1998: 50]. Intensified competition among teachers and students is presented as ,achievement equity'; the introduction of school fees becomes 'cost-sharing' and the plea for new structures of control turns into 'cooperative autonomy' [Bennhold 2002: 293]. The current restructuring of the education system can be characterized by a combination of external- and self-subjection. Its essential effect consists of producing what Simons (following Foucault) calls the ,will to quality'. It brings together ,advanced liberalism, the permanent 
economic tribunal and the enterprising self" [Simons 2002: 619]. The advanced form of neoliberal governmentality in the education system arises from the linkage of the apparatus with the incessant demand for self-management. „Referring to Foucault, we could define actual 'managementality' as management of self-management, with the constitution of an economic tribunal as the permanent point of reference" [622].

- Total quality management, which has established itself as the driving motor of the transformation of educational institutions, is entirely true to its totalitarian claims: while it demands incessant procedures of individualisation (of organisations as well as individuals), at the same time it promotes "totalisation through modern power mechanisms" [Foucault 1987: 250]. The freedom of the enterprise „I \& Co. "[Bridges 1996] consists of the voluntary self-control and self-subjection to a permanent and comprehensive economic tribunal (put into practice by management consultants). They correspond to a permanent self-examination and evaluation. The contemporary ,microphysics of power' leaves the old techniques of surveillance and punishment behind; instead its works with benchmarking, quality audits, empowerment and tests [Lemke, Krasmann, Bröckling 2000: 35].

However, although one's own position in the quality ranking is always only relative to one's competitors, the push for improved performance never stops. Everyone occupies simultaneously and to the same extent the role of the competition judge and contestant, the winner and the looser, the selfentrepreneur and the serf. Where the dictatorship of comparison reigns, there - adapting Hegel - the world market becomes Supreme Court [Bröckling cited in Bröckling, Krasmann, Lemke 2000: 162].

Given this account of the situation, one might be tempted to throw in the towel. But this would be to seriously underestimate the ambivalent operation of the new strategies of control. Just as these strategies aim to subject individuals to a 'voluntary self-control', they are equally directed towards not just allowing but precisely demanding new spaces for self-realisation and new practices of subjectification. In reality governmental strategies are in themselves contradictory: they demand individuals' active, self-chosen and desired integration into strategically organized contexts. To realize this, however, they permanently have to open up spaces of freedom and also demand that they be utilized. This is why the constant propaganda of educational reform focuses on teachers and learners adopting the new freedoms. Seen in this way, all governmental strategies imply 'breaks' or, in other words: they contain a necessary moment of difference, which critique can then focus on. 


\section{Breaking points: discontinuity, reflexivity, critique}

Given the ripple effects of the reform measures in the education system, it seems to me not entirely straightforward to keep these breaking points or faultlines in pedagogic practice in view. The fact that these faultines remain unavoidable is one of the irritating experiences of real reform activity. In order to show this, I would like to take the liberty of a short detour: a side glance at industry's innovative production sectors, especially in the field of the forms of work characterising the information and service, or postmodern, (,informatised') economy. When one speaks of ,manageability', ,employability', or ,entrpreneurship', one finds that these concepts are bound up with particular practices of subjectification, without which the new productive demands would rest on thin air. For the new ,subjectifying forms of labour', subjectification constitutes (in contrast to earlier conceptions of production) not an obstacle to frictionless production, but a condition of production. Systematic concepts of production utilise models of steering which move across a field stretched between autonomy and control [Schroeder 2002: $41 \mathrm{ff}$.]. The chains of production steered by information technology have a particular requirement in relation to subjectivity: they demand a subjective agreement about the meaning-structure of the production process.

As a result, entrepreneurial authorities have an understandable interest in promoting the required reflexivity in such a way that it is confined to corporate goals of rationalisation. However, this self-confinement can no longer be simply decreed. This is why modern enterprises operate with ,soft' management forms, with animation or suggestion, in short: with,whispered emancipation' [Fach 2000: 121]. They focus so sharply on individuals that the network of demands and protests falls out of view. Their goal is, however, easy to intepret: namely, to turn into self-management, to bring people to optimise their ,inner entreprise', to become their own quality managers that is, to become not just ,entrpreneurs' but intrapreneurs'. But the reflexive moment of the labour process does not remain imprisoned like a genie in the bottle. The new corporate management generates its own discontinuities: the capacity for critical reflection on ones owns presuppitions and attitudes, the capacity for self-distance and self-limitation. The way in which the technological society has to become self-reflexive also brings forth the means of gaining a distanced perspective [Pongratz 2010: 135]. The ,danger' now arises objectively - as Heydorn formulated it - that the subject,emerges from the sum of their functions and refers back to themselves' [Heydorn 1980: 290]. 
I have here engaged with the inherent contradictions of the new conditions of production initially from the perspective of industrial sociology. But an occupational field has to determine much more: questions of self-management and management of others, self-articulation and enhancement, in short: questions of education, which constitute the core of professional selfunderstanding and everyday action. From this perspective it is no surprise that the establishment of governmental strategies should be realised above all in relation to the education system. Still less can we be surprised, however, that the contradictions of this implementation process manifest themselves in the education system.

One can thus make some conjectures about where and how the current reforms will run aground. I would agree with Sven Opitze, who outlines the problematic of the neoliberal programme in a discussion with Tilman Reitz und Susanne Draheim as follows:

If programmes are both symptoms and matrices of governmentality, they are still by no means the guarantee, let alone the proof of a frictionless functioning. [...] Programmes constitute [...] hegemonic structures which are always capable of being overturned. They aim to operationalise and fix in place a particular hegemony, but are themselves the product of powers which have already begun to turn them into ruins. One should thus regard a programme as a ruin, and analyse it accordingly [Draheim et al. 2005: 6].

This suggestion strikes me as persuasive: we should - in opposition to rampant efficiency and autonomy rhetoric - not just consider the ruinous effects of the current reform programme, but also, above all, the ways and means by which it undermines itself. We should analyse it as a future ruin'.

\section{References}

Arnold, R., Siebert, H. 1995. Konstruktivistische Erwachsenenbildung. Hohengehren: Schneider.

Bennhold, M. 2002. Die Bertelsmann Stiftung, das CHE und die Hochschulreform: Politik der ,Reformen' als Politik der Unterwerfung. In Lohmann, I., Rilling, R. (eds.) Die verkaufte Bildung. Opladen: Leske u. Budrich, 279-299.

Bourdieu, P. 1998. Gegenfeuer. Konstanz: edition discours.

Bröckling, U. 2000. Totale Mobilmachung. Menschenführung im Qualitäts- und Selbstmanagement. In Bröckling,U., Krasmann, S., Lemke, T. (eds.) Gouvernementalität der Gegenwart. Frankfurt/M: Suhrkamp, 279-299.

Deleuze, G. 1992. Postscript on the Societies of Control. October 59, 3-7.

Deleuze, G. 1995. Postscript on Control Societies. In Negotiations 1972-1990. New York: Columbia University Press, 279-299. 
Draheim, S., Opitz, S., Reitz, T. 2005. Blindheit und Einsicht? Wortwechsel zum Gebrauchswert der Gouvernmentalitaetsstudien. In Forum Wissenschaft, [online] <http://www.bdwi.de/suchen/97726.html?searchshow=blindheit und einsicht>

Erpenbeck, J. 2001. Selbstorganisiertes Lernen - Ausdruck des Zeitgeistes oder Ausdruck der Zeit? In Hoffmann, D., Maack-Rheinländer, K. (eds.) Ökonomisierung der Bildung.Weinheim: Beltz, 199-214.

Fach, W. 2000. Staatskoerperkultur. Ein Traktat über den ,schlanken Staat‘. In Bröckling, U., Krasmann, S., Lemke, T. (eds.) Gouvernementalität der Gegenwart. Frankfurt/M: Suhrkamp, 110-30.

Fischbach, R. 2002. Die Wissensgesellschaft. Maßstab oder Phantom der Bildungsdebatte? In Widersprüche, 22(83): 9-22.

Foucault, M. 1977. Discipline and Punish. London: Allen \& Unwin.

Foucault, M. 1987. Das Subjekt und die Macht. In: Dreyfus, H. L., Rabinow, P.: Michel Foucault - Jenseits von Strukturalismus und Hermeneutik. Frankfurt/M.: Suhrkamp: 243-264.

Heydorn, H.-J. 1980. Überleben durch Bildung. Umriss einer Aussicht. In Ungleichheit für alle. Bildungstheoretische Schriften. Frankfurt/M.: Syndikat: 282-301.

Kost, F. 1985. Volksschule und Disziplin. Zürich.

Lemke, T. 2000. Neoliberalismus, Staat und Selbsttechnologien: Ein kritischer Überblick über die Governmentality Studies. In Politische Vierteljahresschrift, 41, 31-47.

Lemke, T., Krasmann, S. 2000. Gouvernementalität, Neoliberalismus und Selbsttechnologien. Eine Einleitung. In Bröckling, U., Krasmann, S., Lemke, T. (eds.) Gouvernementalität der Gegenwart. Frankfurt/M: Suhrkamp, 7-40.

Lessenich, S. 2003. Soziale Subjektivitaet. Die neue Regierung der Gesellschaft. In Mittelweg, 36:80-93.

Pongratz, L. A. 2004. Freiwillige Selbstkontrolle. In Ricken, N., Rieger-Ladich, M. (eds.) Michel Foucault: Paedagische Lektueren. Wiesbaden: VS-Verlag, 243-60.

Pongratz, L. A. 2005. Subjektivitaet und Gouvernementalitaet. In B. Hafeneger (eds.). Subjektdiagnosen. Schwalbach/Ts: Wochenschau Verlag, 25-38.

Pongratz, L. A. 2010. Kritische Erwachsenenbildung. Wiesbaden: VS-Verlag.

Schirlbauer, A. 1998. Vom Verschwinden des Lehrers in der ,Neuen Lernkultur‘. In Wenger-Hadwig, A. (ed.) Der Lehrer - Hoffnungsträger oder Prügelknabe der Gesellschaft. Innsbruck: Tyrolia, 54-69.

Schroeder, J. 2002. Emanzipation Durch Informatisierte Erwerbsarbeit?. In Institute for All. Paed. u. Berufspaed. Darmstadt: TU Darmstadt.

Simons, M. 2002. Governmentality, Education and Quality Management. In Zeitschrift für Erziehungswissenschaft, 5(4): 617-33.

Voß, G.G., Pongratz, H. J. 1998. Der Arbeitskraftunternehmer. Eine neue Grundform der Ware Arbeitskraft? In Kölner Zeitschrift für Soziologie und Sozialpsychologie, 50, 131-58. 


\section{Author:}

Ludwig A. Pongratz, Ph.D., Professor

Technische Universität Darmstadt

Institut für Allgemeine Pädagogik und Berufspädagogik

Alexanderstrasse 6

64283 Darmstadt

Germany

Email: I.pongratz@apaed.tu-darmstadt.de 